\title{
本学におけるエ業教育の目標
}

\author{
野 田清一郎 \\ (大阪工業大学長)
}

\section{I 近世科学技術の発達}

大学は法交学亚びに自然利学の研究とその教育とに嚆し最高学府として誕生したのであ るが, 後世工業技術の発達に伴いその研究と教育とがまた大学の枠内に這入るようになっ た。近代科学技術が現場で異常な進歩を゙見た今日でるこの性格はな招認められている。

工業挍術が各国民生活の重要地步を占むるに至り，政府その他の公共団体住各種利学挍

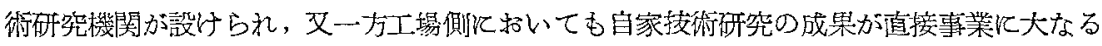
寄与をなし，重要な発明が次から次と工場で産れてきたので，事業界が工業技術の研究に 大なる関心を持つに至った。一方大学性社会の要望答えて青年教育が主な職責となり，

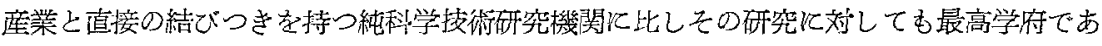
るとの性格に若干の疑点ぶ生してきた。

近代の戦争では優秀な武器が戦勝の主要素となったので, 各国とも軍備に最大の熱を持 ち, 戦争に際しては, 全国力を锗して武器の生産に遇進し, その研究努力により武器とそ

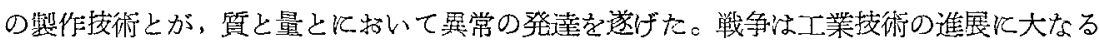
寄与をなす。第一次世界大戦沉扔いて主役を演じた米国で，戦争用武器の增虐と新兵器 の研究とに就し主として大工埸を動員してこれに当らしめた。戦争の刺激によって生れた 接術と生産品との終戦後の平和利用を担当した工場の生産目標の变化と種目の增大とが， 更に技術㪯用の新分野を開拓した。たと党ば鉄鋼工場の抬大と電子工学々の発達とが終戦

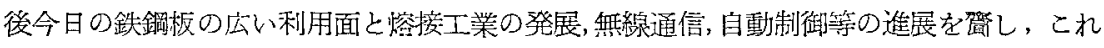

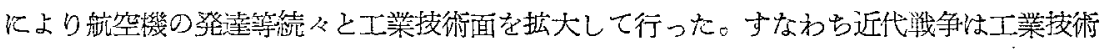
革命の大役を演じ，終茷挠の世界産業経済の偉大なる変化発展を招来する。ただここで一

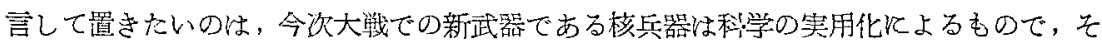
の研究には炭大な設倩と経費とを要するので，前の憬合と異り政府が事策管理の主体者と なり，大学と工場とがこれに参加したのである。しかしてその研究は今日い季た完成の域

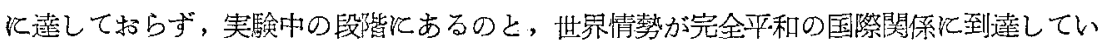
ないので世界の話題となっている。米国ですいまだこれを工場に移管して，平和社会に曹 
用せしめ得る域に達していない。

前戦争以来世界挍術の最高担当者となった米国の大工場では，新製品の座出と新工作法 とに大なる興朱学持ち，工業技術の研究を重視し，それに大なる資金を投ずるに至った。 これら大工場の研究所は，基礎利学からその利用面まで，すなわち科学とその流用面えの 導入に至るまでの全体を担当する。更に工場の規模の拡大に伴い経営管理等人文科学の分 野にまでその研究の手を延すに至った。

米国大工場の生库品なその機能が使用面沉括いて適当であること艾唯一の目標として製 作せられて招り，これを科学技術的に検討してその材料，工作法等申し分なきを期してい るが，更にこれら製品の存在がその日常使用者に好感を与えることも必要であるとの見解 から，彆品の美術的見地からの検討む行われるようになった。筆者の Westinghouse 会 社の幹部技術者から聴いたのでは, 機器設計棈成が科学的であることが概ね美学面からの 批判によよ合致する。しかし，この美学的面に颃いて更に研究を進めてみたいと。な标 同氏は日本で古くから行われている華道は, 我々工業技術者の立場からも興味ある教養で あると語られた。同会社では互に密接な提㨨関係にあるPittsburg University で美学 の講義を恥請するよう同会社の技術者達に薦めていた。

数值計算の徹底せる米国座業界で主，工場の研究部門の拡大山大学の場合上異り，その 奻果の資本的判定が確奏であるので, 研究に対する配人と設備とに対する投资額は合理的: に計算せられている。故に大工場が去の研究に多数の有能学者を当て, 原理から実地放術 までの求大な研究設倩を持つに至ったの屯, 事業経営面からの価值判断に基くのである。

米国大工場の研究は，人類文化の向上という古い大学精神による視野からでなく，事業 経営の一翼としてのものであるから，優れた斫究成果は，それが夷用化の域に達するまでは 一切秘密に保たれる。工科丞学会での研究発表が米国技術者焦步の先端項目を網羅指示す るものと誤解してはならない。業界からの研究発表は出来上った機器の構成と動作，また はこれらに伴う理論であって，去の成果があがるまでのあらりる研究業績は極秘である。

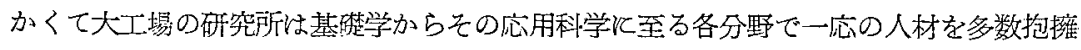
するのみならず，現場にす各部局にむ夫々有能接術人を各職場に配置している。工業技術 が日進月步の現状に执いては工科系大学はとの最高学府たる挑点を大工場に譲らねね゙なら ぬ域に来た。

\section{II 大学に扣けるエ業教育}




\section{1 米国大工場の要望}

終戦後の平和社会に括いて工業界が社会の大なる部面を占むるに至り，工業企業界はを の規模益々抬大せられ，将来性のある青年技術者を多数採用せんと欲する汇至ったことは 当然である。米国の大工場では上述のごとく，基礎学から純挍術に至るまでの最近の工業 発展に資す研究と現業とに多数の卓越せる有能人を用いてこれて当らさせているが，新規 探用の青年に最新最高の技術教育を授けるのに，設㑽にも教育担当者にむこと欠かぬ状態

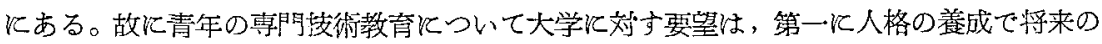
高級社会人たる素質を盖うことが，工場としての最す希望する点であり，次いで基楚学の

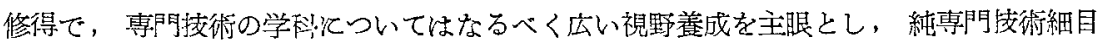
漖育については大学に低存することなく，工場自家に括いてこれを受持つという現状にあ る。大学側としては職責極めて安易となった。

\section{2 大阪に抿りる本学の立場}

世界大戦に基く工業技術の偉大なる発展，しこうしてその平和利用の多種多方面への進 出が米国を主体として全世界を動かしている現状に竹いて，我国の工業界もとの波にのっ て空前の繁栄を罆らした。わが国特に大阪の工業界には, 若干数の大企業は存在している が，種別と数とに話いて，や悢り中小工業が産業界の大なる部面を占めている。昔から近 畿地区と瀬戸内海沿岸の中国, 四国から北九州飞及ぶ地方の商工業の中心地格であっ た。この大阪中心の傾问は今日もな結いている。これら辺地の農民の子弟が唯一の成功 の地として大阪に集ってきた古い習慣は今も変らぬ。その教育面で昔の徒弟主体から商 工業学校, 大学と進んできた。最近わか国の経済組織に工業が强く盛られてきたので，こ の傾向は一層強化せられてきた。かくて大阪の工科大学としては，これら中小工業界に進

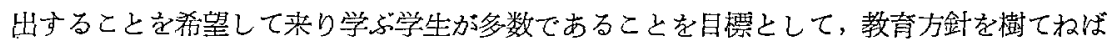
ならない。

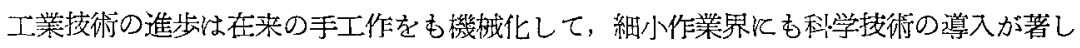
くなったので，今日では極小工作工場む新しい工業技術の採用に熱を入れるようになっ た。交通運輸の便そ伴い，大都市大阪に限らず各僻地の小市町村でる業者の多種類が工業 技術導入に熱心になってきた。

今日わが国の工業技術は稍々立ち遅れの感があり，大工場では外国技術の輸入が目立つ

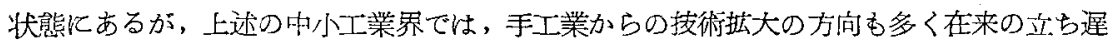
れを補うので，必ずしむ最近発澾つ技術のみを採り入れんとするものだけではない。ただ 
在来既知の技術でもこれを新しい小工業界沁応するには相当の研究が必要となる。この 点大服の工業大学としては研究成績を挙げ得る可能の面が相当ある。

美術姜重心つ强いわが国の工業製品は，実地使用の便を主目的とする米国等と正反刘论 体裁本位て実用面つ適正化の检詥が足ら双点が多い。また外国接術を尊入するにも，わが 国库業の特殊性に爁み研究すべき余地すある。一方わが国在来の特烄を新しい工業技術分 拏応用開登する必要もある。

建籍工学面で火災，台風，豪雨の被害の甚しいわが国では，単に欧米式でないが国 独特の研究で新しい構䑁につき検討の余地があうう。

大阪附近の小鋳物工場で，その操作資源の質質に大なる悩みを感している。これに获 し本学教授はその打開法研究に精進している。また小船舶用プロペラー製造業者の後継者 を養成して在来苦心を重悋てきたプロペターの塩害損傷防此の研労炕当らしめている。

本学では，世界技術進歩の大勢汇は立ち遲れの感はあるが，实地工業技術に多年の経験 ある教授陣によって工業技術の仦企業への応用面を考光て学生の教育汇当っている。

\section{3 本学学生 0 素孟}

上述の中小企業の幹部㐫，自営業者自体で現場での工夫で何とか経営して来たのである が，ての業務委託のできる後継者を近親より得て，新時代の業界住心してマッチして行 きたい念願は强い。ところが次代の青年は環境があまりにむ恵まれて育ったので進学欲が 少い。仮令あっても本人の趣味本位で必ずしも家業の方向炕そわ收。これが古来大阪商人 を批評する言葉，親苦于楽で，次いで来る孫筫が経営者の最大痛心事であった。今日では わが国の教育制度が整備せられたので，これら業者達つ子供炕も大学進学者が多くなり， 特汇法経柔の大学就学が主であるので, これら経営者は一応安心し得た面が多い。しかし 工場経営者としては，新しい技術導入の頻繁になった今日では，自家に技術柔大学卒詳者 の無いのは最大の心配事である。これら業者の子弟の進学希望者を収容して，工利大学教 育を授けるととは，わが国とくに大阪での産業に奇与する点が大であると思う。ただこれ ら子弟は人柿江温和で交友関係む良いが，勉強心の薄い者が多い。その教盖には特に注意 を要する。この種類の学生は，自家独自の現場作業に明確な知識を持っている故その専 闍教養汇関しては適切な希望があり，また特殊題目につき興味ある問題も自発的に出てく る。この点教育指導は楽である。彼等の多くは專門基整学を充分盖光ば，あとは自登的に

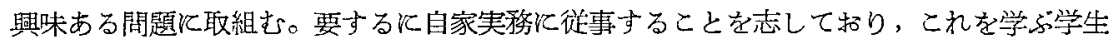
の補導は楽である。 


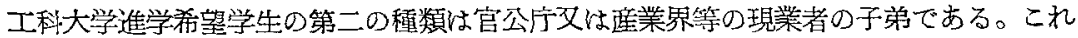
らはわが国大学学生の最む普通の型でごこで迹べるまでもなからう。

第三の種類は田舎僻地からの来学者である。これら学生の卒業後の就職問題について考

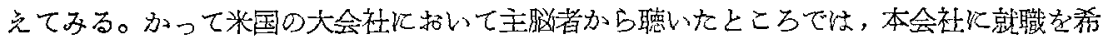
望して来る大学卒業生は, 全米各州からであるが, その出身地により夫及性格の相違があ る。その良業方面化沁じて最適の地方人を選足採用すると。放が国です東京のある大会社 で九州春らの新卒業生をとの鄉里に即した性格人の真京勤務に適する場所ありとて, 喜ん で探用して寔ったことがある。商都大阪では，中国，四国の僻地農村子弟を雇菻する古い 習慣が今日もまだ残っている。大学卒業生の地方別性格相違の点を採用者側で考慮の余地 はなからうか。

\title{
本学におけるエ業教育の改善
}

\author{
後藤文婎 \\ (九州工業大学教授)
}

\section{1 難 しい課 題}

第一に本課題は, 各大学で工業教育上改善された事柄を, 学長乃至代表者がまとめて報 告したうが適切のような気がする。同し大学で教官が個人的に改善した事賣であって，未 だとれが全学的になっていな名案もあるうと思机れる。李等しく工業教育と称しても， 專門的な面から工業人としての一般教盖の面まで含むので，解鄱の仕ちでなかなか悻等が 難しい譟題になって来るようである。

\section{2 工業教育協会への集団加入}

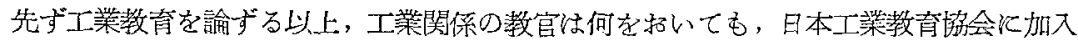
することが先決で，万事はその後と思う。という訳で本学で性，学長の惩汿により昭和31 年度に，未加入の專門科教官が全員加入した外，英語，社会，体育など人文関係の教官の Zかか，事務局の文部事務管まで一举に集団加入した。これが本学に括ける工業教育の改善 に対する心構党の第一歩である。 